\title{
Evaluation of a new technique for the demonstration of gonococci and other micro-organisms in host cells
}

\author{
C. SOWTER ${ }^{1}$ AND Z. A. McGEE \\ From the Divisions of Cell Pathology and Communicable Diseases, Clinical Research Centre, Harrow \\ HAI $3 U J$
}

SYNOPSIS A method (Gram-MGPLG) for demonstrating micro-organisms was compared with Gram and four other known methods. Each method was tested on tissue infected with Staphylococcus aureus, Pseudomonas aeruginosa or Neisseria gonorrhoeae, which were then fixed in Bouin's formol saline, formol sublimate, or Van de Grift solutions. Gram-positive organisms in tissues were easily seen even at low magnification when stained by several of the methods tested.

Gram-negative organisms, however, are very difficult to locate when stained by Gram's method because tissue components and the organisms are all shades of red, whereas the Gram-MGPLG provided easier location of organisms because these are stained red while the nuclei are blue and connective tissue is green.

All methods are markedly affected by fixation; better preservation of cytological detail and improved staining reactions were produced by fixatives containing mercuric chloride.

During studies of the interaction of gonococci with fallopian-tube tissue in organ culture, it was found that Gram's technique, although staining bacteria well, failed to demonstrate cytological detail and, because it stains Gram-negative organisms and tissue elements different shades of the same colour, did not permit clear differentiation of bacteria from either the nucleus or cytoplasm, thus making interpretation of the sequence of events in the infection difficult. Rather than rely on the use of the electron microscope, we searched for a histopathological technique that would provide this information. Accordingly, five of the methods most often recommended for staining bacteria in pathological material were systematically compared with the method which we have developed in this laboratory.

\section{Material and Methods}

\section{ORGANISMS}

The bacterial strains used in this study were Neisseria gonorrhoeae, strain 192A, colony type 1, Staphylococcus aureus, strain NPH30903, and Pseudomonas aeruginosa, strain NPH27559.

\footnotetext{
${ }^{1}$ Requests for reprints to: C. Sowter, Animal Histopathology, Department of Pathology, Northwick Park Hospital, Watford Road, Harrow, Middlesex HA1 3UJ

Received for publication 6 November 1975
}

MEDIA

All bacteria were grown at $37^{\circ} \mathrm{C}$ on $\mathrm{GC}$ agar base (Difco) supplemented with $2 \% \mathrm{v} / \mathrm{v}$ Isovitalex (BBL). The medium for maintaining fallopian tubes in organ culture was Eagle's minimal essential medium with Earle's salts buffered with 0.05M N-2-hydroxyethylpiperazine- $\mathrm{N}^{\prime}-2$ ethanesulphonic acid (HEPES, Gibco) adjusted to $\mathrm{pH} 7 \cdot 45$ with $1 \mathrm{~N} \mathrm{NaOH}$.

\section{FALLOPIAN TUBES IN ORGAN CULTURE}

Fallopian tubes were obtained from non-pregnant premenopausal women undergoing hysterosalpingectomy for uterine fibroid tumours. The tubes were placed in glass Petri dishes in the operating room and delivered to the laboratory within 20 minutes of removal. After removal of the serosal tissues, the fallopian tube was opened by longitudinal incision and the ampullary region was cut into pieces $3-4 \mathrm{~mm}$ square. Three pieces were put into each organculture dish.

\section{INFECTION OF FALLOPIAN-TUBE ORGAN CULTURES}

Bacteria cultured for 18-22 hours were scraped from the surface of the medium with a wire loop and suspended in $0.05 \mathrm{M}$ HEPES. The concentration of organisms was adjusted by dilution with $0.05 \mathrm{M}$ HEPES so that the suspension contained approximately $2 \times 10^{6}$ colony-forming units per $\mathrm{ml}$. The 
organ cultures were inoculated with $0.2 \mathrm{ml}$ of this suspension and incubated at $37^{\circ} \mathrm{C}$ in airtight plastic boxes that had been flushed with $5 \% \mathrm{CO}_{2}$ in air. Three sets of fallopian-tube organ cultures were infected with Staph. aureus, Ps. aeruginosa, or N. gonorrhoeae.

FIXATION AND PROCESSING OF TISSUES

Twenty-four hours after inoculation the organ-culture pieces were transferred to vials containing one of four different fixatives: (i) Bouin's solution; (ii) formol saline; (iii) formol sublimate (formulae for i, ii, iii of Drury and Wallington (1967)); (iv) Van de Grift's solution (Dajani et al, 1965). After 20 hours in fixative the tissues were dehydrated in graded alcohols, cleared in toluene, and embedded in paraffin wax, and microtome sections were cut $4 \mu \mathrm{m}$ thick.

STAINING OF TISSUES

The following staining techniques were used: (1) Gram (Lillie, 1965); (2) Murray-Drew (Murray, 1919); (3) Brown-Hopps (Luna, 1968); (4) BrownBrenn (Dajani et al, 1965); (5) Gram-Twort (Drury and Wallington, 1967); (6) Gram-methyl greenpyronin-light green (Gram-MGPLG technique, developed in this laboratory during these studies).

The Gram-MGPLG technique was similar to Gram's technique (Lillie, 1965) except that counterstaining with safranin was replaced by the following steps: (1) stain 30-40 minutes in the methyl green-pyronin solution (described below); (2) rinse in distilled water; (3) stain for 10-15 seconds with $0.5 \% \mathrm{w} / \mathrm{v}$ light green, colour index (CI) 42095, in distilled water; (4) rinse in distilled water; (5) blot; (6) transfer directly to absolute ethyl alcohol for 5-10 sec; (7) transfer to xylene until the section is clear; (8) mount in a synthetic-resin medium. The methyl green-pyronin solution was made by combining methyl green, CI $42585,0.15 \mathrm{~g}$; pyronin, CI 45005 , $0.5 \mathrm{~g} ; 96 \%$ ethyl alcohol $2.5 \mathrm{ml}$; glycerin, $20 \mathrm{ml}$; and $100 \mathrm{ml}$ of $0.5 \% \mathrm{w} / \mathrm{v}$ crystalline phenol (Analar) in distilled water. These materials were mixed with chloroform $100 \mathrm{ml}$ and allowed to stand overnigh The stain, which was the top layer, was removed carefully to avoid contamination with chloroforr. The stain should be returned to the bottle and ret used for 3-4 months. All dyes were obtained fro Raymond A. Lamb Ltd, 6 Sunbeam Road, Londo NW1D 6JL.

\section{Results}

The 72 histological sections were examined determine the colour of the nuclei, cytoplasrif collagen, and microorganisms. Table I shows whiest stains differentiated bacteria from cellular element? For example, with Gram's stain, Gram-negatike bacteria may be difficult to see because the tissue elements and microorganisms were various shades of red, whereas with the Brown-Hopps technique bacteria were different in colour from the surrounding tissue elements and were, therefore, more easily distinguished.

These results, however, did not take into account the effect of different fixatives on preservation \& cytological detail and particularly on subsequerit staining reactions. A systematic evaluation of the 24 fixative-stain combinations was therefore pes formed. The 72 sections, which had been coded so that the fixative and stain were unknown, wer\% independently evaluated by two observers. S features were evaluated and graded on a scale of 0 to $4+$; they were: (1) organisms seen clearly wit $\$$ a $10 \times$ objective; (2) organisms seen clearly with $40 \times$ objective; (3) organisms visible outside cellș (4) organisms visible in cytoplasm; (5) organism distinguishable from nuclear debris; (6) definition of cytological detail-clear cellular boundaries ang differentiation of cellular components. Features. 3 to 6 inclusive were evaluated with a $63 \times$ oip immersion objective. The scores of the two observers were averaged and the mean was expressed as tho percentage of the total possible score. The results were collated to permit analysis of the effect of eact fixative-stain combination on a single feature suck

\begin{tabular}{|c|c|c|c|c|c|}
\hline \multirow[t]{2}{*}{ Staining Technique } & \multicolumn{5}{|l|}{ Colour of } \\
\hline & Nuclei & Cytoplasm & Collagen & $\begin{array}{l}\text { Gram-positive } \\
\text { Bacteria }\end{array}$ & $\begin{array}{l}\text { Gram-negative } \\
\text { Bacteria }\end{array}$ \\
\hline $\begin{array}{l}\text { Gram } \\
\text { Murray-Drew } \\
\text { Brown-Hopps } \\
\text { Brown-Brenn } \\
\text { Gram-Twort } \\
\text { Gram-MGPLG }\end{array}$ & $\begin{array}{l}\text { dark red } \\
\text { blue }^{1} \\
\text { red-brown } \\
\text { dark red } \\
\text { brown-red }{ }^{2} \\
\text { blue }\end{array}$ & $\begin{array}{l}\text { red } \\
\text { pink } \\
\text { yellow } \\
\text { red } \\
\text { green } \\
\text { green-blue }\end{array}$ & $\begin{array}{l}\text { pink-red } \\
\text { red-yellow } \\
\text { yellow } \\
\text { pink red } \\
\text { green } \\
\text { green }\end{array}$ & $\begin{array}{l}\text { blue } \\
\text { blue } \\
\text { purple } \\
\text { purple } \\
\text { purple } \\
\text { magenta }\end{array}$ & $\begin{array}{l}\text { red } \\
\text { blue } \\
\text { red-purple } \\
\text { red } \\
\text { brown-red } \\
\text { scarlet-red }\end{array}$ \\
\hline
\end{tabular}

Table I Colours of tissue elements and microorganisms with various bacterial stains

${ }^{1}$ Nuclei and cytoplasm were yellow in tissue fixed in Bouin's fixative.

${ }^{2}$ Nuclei had green tint in tissues fixed in Bouin's fixative. 


\begin{tabular}{lllll}
\hline Staining Technique & \multicolumn{4}{c}{ Mean Scores $^{1}$ of Tissues fixed in: } \\
\cline { 2 - 5 } & Bouin & $\begin{array}{l}\text { Formol } \\
\text { Saline }\end{array}$ & $\begin{array}{l}\text { Formol } \\
\text { Sublimate }\end{array}$ & $\begin{array}{l}\text { Van de } \\
\text { Grift }\end{array}$ \\
\hline Gram & 42 & 54 & 46 & 67 \\
Murray-Drew & 29 & 58 & 42 & 71 \\
Brown-Hopps & 21 & 67 & 79 & 67 \\
Brown-Brenn & 29 & 46 & 67 & 54 \\
Gram-Twort & 17 & 79 & 75 & 79 \\
Gram-MGPLG & 29 & 75 & 92 & 92 \\
\hline
\end{tabular}

Table II Evaluation of the effect of fixative-stain combinations on definition of cellular boundaries and differentiation of cellular components

${ }^{1}$ Percent of maximal score

as differentiation of cytological detail (table II) or on all features in aggregate (table III). These results are discussed below.

STAINING OF GRAM-POSITIVE ORGANISMS IN TISSUES

All staining techniques differentiated Staph. aureus from cytoplasm and collagen. Thus, the organisms were easily seen even at low magnification. With the Gram, Brown-Hopps, Brown-Brenn, Gram-Twort, and Gram-MGPLG techniques the organisms were also different in colour from the nuclei and therefore were distinguishable from nuclear debris.

Because Staph. aureus could be distinguished from tissues by any of the techniques, the optimal fixativestain combination for tissues infected with staphylococci might be the one that best demonstrated cytological detail. Cytological detail was demonstrated well by the Gram-MGPLG stain with formol sublimate or Van de Grift's fixative; Gram-Twort with any fixative except Bouin's; and Brown-Hopps with formol sublimate (table II). These combinations also had high scores when other features were evaluated (table III). Thus, these fixative-stain combinations would be suitable for experimental studies with staphylococci.
STAINING OF GRAM-NEGATIVE ORGANISMS IN TISSUES

The demonstration of Gram-negative organisms was far more difficult because by four of the staining techniques the organisms were the same colour as the nuclei or cytoplasm (table I). Only by the BrownHopps or Gram-MGPLG technique was it possible to differentiate chromatically Gram-negative bacteria from nuclei, cytoplasm, and collagen. Because either Brown-Hopps or Gram-MGPLG with formol sublimate demonstrated organisms in tissues, both combinations would be suitable for studies on Gram-negative organisms. However, because the Gram-MGPLG was superior to the Brown-Hopps in demonstrating cytological detail (table I), it was the fixative-stain combination of choice.

To compare the Gram-MGPLG with Gram's technique, serial sections of fallopian tube infected with $N$. gonorrhoeae were stained and viewed with $10 \times$ and $63 \times$ objectives. A comparison of figs 1 and 2 illustrates the greater ease of locating bacteria stained with the Gram-MGPLG technique and demonstrates a focus of mucosal infection not seen with Gram's stain. Figs 3 and 4 illustrate that the Gram-MGPLG technique is superior to the Gram technique in preserving cytological detail and demonstrating the relationship of bacteria to host cells.

EFFECT OF FIXATIVES ON THE STAINING OF BACTERIA IN TISSUES

As shown in tables II and III, the fixatives significantly influenced the performance of the various stains. The poorest results were usually obtained when Bouin's fixative was used. Of the remaining fixatives, results depended on the stain but all gave generally good results. For instance, although formol saline was an adequate fixative for most stains, formol sublimate and Van de Grift's fixative produced greater intensity of staining and brilliance of colour with the Gram-MGPLG stain.

\begin{tabular}{|c|c|c|c|c|c|c|c|c|c|c|c|c|}
\hline \multirow[t]{3}{*}{ Staining Technique } & \multicolumn{12}{|c|}{ Aggregate Scores ${ }^{1}$ of Six Features ${ }^{2}$ for Tissues infected with: } \\
\hline & \multicolumn{4}{|c|}{ Staph. aureus fixed in } & \multicolumn{4}{|c|}{ Ps. aeruginosa fixed in } & \multicolumn{4}{|c|}{$\mathbf{N}$ gonorrhoeae fixed in } \\
\hline & Bouin & $\begin{array}{l}\text { Formol } \\
\text { Saline }\end{array}$ & $\begin{array}{l}\text { Formol } \\
\text { Sublimate }\end{array}$ & $\begin{array}{l}\text { Van de } \\
\text { Grift }\end{array}$ & Bouin & $\begin{array}{l}\text { Formol } \\
\text { Saline }\end{array}$ & $\begin{array}{l}\text { Formol } \\
\text { Sublimate }\end{array}$ & $\begin{array}{l}\text { Van de } \\
\text { Grift }\end{array}$ & Bouin & $\begin{array}{l}\text { Formol } \\
\text { Saline }\end{array}$ & $\begin{array}{l}\text { Formol } \\
\text { Sublimate }\end{array}$ & $\begin{array}{l}\text { Van de } \\
\text { Grift }\end{array}$ \\
\hline $\begin{array}{l}\text { Gram } \\
\text { Murray-Drew } \\
\text { Brown-Hopps } \\
\text { Brown-Brenn } \\
\text { Gram-Twort } \\
\text { Gram-MGPLG }\end{array}$ & $\begin{array}{l}75^{1} \\
69 \\
73 \\
90 \\
90 \\
83\end{array}$ & $\begin{array}{l}92 \\
75 \\
85 \\
90 \\
90 \\
87\end{array}$ & $\begin{array}{l}79 \\
75 \\
96 \\
85 \\
81 \\
92\end{array}$ & $\begin{array}{l}85 \\
71 \\
54 \\
92 \\
92 \\
90\end{array}$ & $\begin{array}{l}42 \\
42 \\
58 \\
48 \\
69 \\
71\end{array}$ & $\begin{array}{l}39 \\
75 \\
79 \\
73 \\
81 \\
87\end{array}$ & $\begin{array}{l}48 \\
75 \\
85 \\
75 \\
75 \\
85\end{array}$ & $\begin{array}{l}50 \\
76 \\
62 \\
65 \\
69 \\
83\end{array}$ & $\begin{array}{l}44 \\
17 \\
23 \\
48 \\
25 \\
79\end{array}$ & $\begin{array}{l}56 \\
38 \\
60 \\
21 \\
44 \\
83\end{array}$ & $\begin{array}{l}58 \\
13 \\
71 \\
50 \\
31 \\
96\end{array}$ & $\begin{array}{l}58 \\
38 \\
77 \\
53 \\
52 \\
92\end{array}$ \\
\hline
\end{tabular}

Table III Evaluation of fixative-stain combinations for studying interaction of Gram-positive and Gram-negative bacteria with tissues 

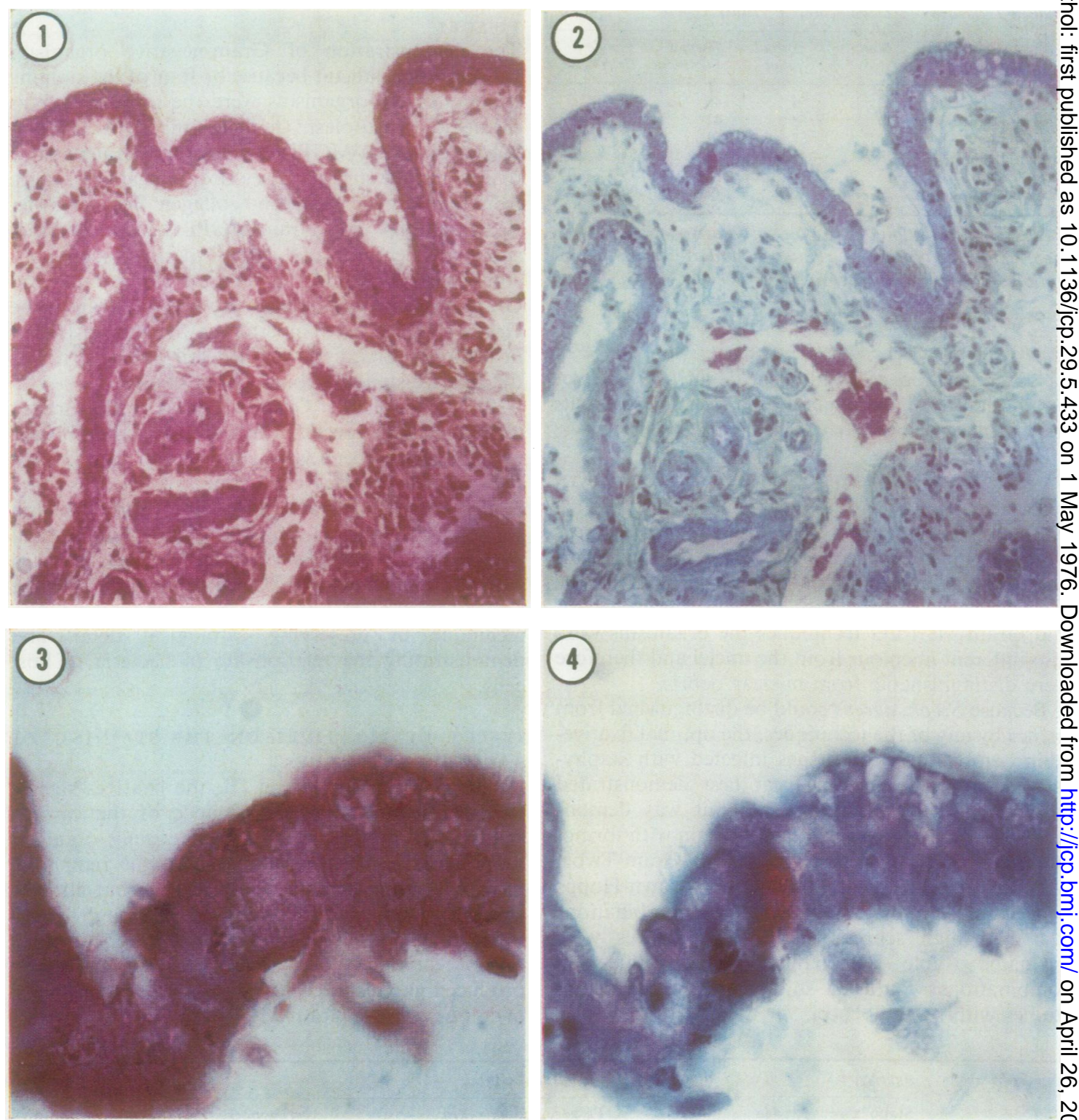

Figs 1 to 4 Sections of human fallopian tube organ cultures. (1) Gram $\times 100$. (2) Gram MGPLG $\times 100$. (3) Gram $\times 630$ iे (4) Gram MGPLG $\times 630$.

\section{Discussion}

Gram's stain, a time-honoured method for determining the presence of microorganisms in tissues submitted for diagnostic examination, is often used in experimental studies to investigate the interaction of microorganisms with host cells. Whereas Gram's stain may be adequate to determine the presence or

absence of microorganisms in tissues, it often faile to supply enough information. Ideally, a stain for investigating the interaction of microorganisms witks host cells should permit localization of bacteria i $\oplus^{+}$ tissue at low magnification; should stain bacteria s\& that they can be clearly distinguished outside cells? in the cytoplasm, and in nuclear debris; and shoul demonstrate the histological features of the tissues 
To meet these requirements a stain would have to differentiate the colour of microorganisms from that of the nucleus and cytoplasm of host cells.

Of the five methods that we tried, several were better than Gram's stain which has the drawback of staining Gram-negative bacteria the same colour as tissue elements and of producing only poor differentiation of nuclei from cytoplasm.

The Gram-MGPLG stain, which had neither of the major defects of the Gram stain, is described in this paper. Methyl green pyronin has been used as a counterstain in the Gram's technique (Scudder and Lisa, 1931). We found this unsatisfactory because, as Scudder described, Gram-negative organisms varied from faded pink to magenta and the cytoplasm of cells was lavender to magenta. Our modification of the original methyl green-pyronin technique (Unna, 1913), when combined with subsequent staining with light green, meets the need to differentiate bacteria from host cells. The component stains, methyl green-pyronin and light green, remain stable for months and give relatively uniform results when used as described.

Although the object of these investigations was to find a fixative-stain combination that would meet the particular requirements of experimental pathological studies, the attributes of such a combination might also make it valuable in routine pathology. Although the colour differentiation of Grampositive and Gram-negative bacteria is not quite as definitive with the Gram-MGPLG as with the Gram technique, this disadvantage seems more than outweighed by the greater ease of detecting organisms that might otherwise be missed. Thus, improved visualization of microorganisms at low magnification and better differentiation of Gram-negative bacteria within densely staining host cells provided by the Gram-MGPLG stain may extend its value to diagnostic pathology.

We are grateful to Mr John Clark and Mr Richard Bowlby for their help with photography and to Dr David Taylor-Robinson, Dr Gerard Slavin, and Mr E. A. Wallington for their review of the manuscript.

This study was supported in part by Research Grant AI-03082 from the National Institute of Allergy and Infectious Diseases, US Public Health Service.

Dr McGee, recipient of Research Career Development Award AI-45045, participated in these studies while a Visiting Investigator from the Division of Infectious Diseases, Department of Medicine, Vanderbilt University School of Medicine, Nashville, Tennessee.

\section{References}

Dajani, A. S., Clyde, W. A. Jnr., and Denny, F. W. (1965). Experimental infection with Mycoplasma pneumoniae (Eaton's Agent). J. exp. Med., 121, 1071-1086.

Drury, R. A. B. and Wallington, E. A. (1967). Carleton's Histological Technique, 4th edition. Oxford University IPress, London and New York.

Lilie, R. D. (1965). Histopathological Technic and Practical Histochemistry, 3rd edition. McGraw-Hill, New York.

Luna, L. G., Ed. (1968). Manual of Histologic Staining Methods of the Armed Forces Institute of Pathology, 3rd edition. Blakiston (McGraw-Hill), New York.

Murray, J. A. (1919). Histological methods of investigating bacteria in tissues. Sci. Rep. Cancer Res. Fd (Lond.), 6, 77-79.

Scudder, S. A. and Lisa, J. R. (1931). A preliminary report on a combined GRAM-PAPPENHEIM stain for formalin fixed tissues. Stain Technol., 6, 51-52.

Unna, P. G. (1913). Die Herkunft der Plasmazellen. Virchows Arch. Path. Anat., 214, 320-339. 